\title{
PETER THE MUSEUM MENSCH: A PERSONAL MUSEOLOGICAL REFLECTION
}

\section{LÉONTINE MEIJER-VAN MENSCH}

\section{The photograph}

I can imagine that a lot of people have 'a most favourite photograph' of their spouse, or another person that is dear to them. A photograph that shows it all, a photograph in which the essence of that particular person is captured in a distilled way. For me it is the 1961 photograph of Peter as a young boy, working on his scrapbook. He just had turned fourteen years old and he was spending the summer holidays with his parents and his younger brother in Spain. It is the dedication, focus and curiosity of that young boy that I find so typical for him. It is as if his whole being was already formed in 1961 . I am convinced that without this dedication and focus he never could have made this profound contribution to museology.

It is not too much of a bold statement to write that Peter van Mensch dedicated his life to the theory, practice and ethics of museums and museology. $\mathrm{He}$ is Mister Museology! Since Peter and I are a 'museological couple' it is difficult to distinguish between our private and professional lifes, but I know that also before 'my time', Peter's dedication to museology was that of a zealot.

Most of all this childhood photograph reveals curiosity. Above all things Peter van Mensch is a profoundly curious person. Always interested and open for new input and thoughts, in- and outside our museological domain. A curious person, gifted with such

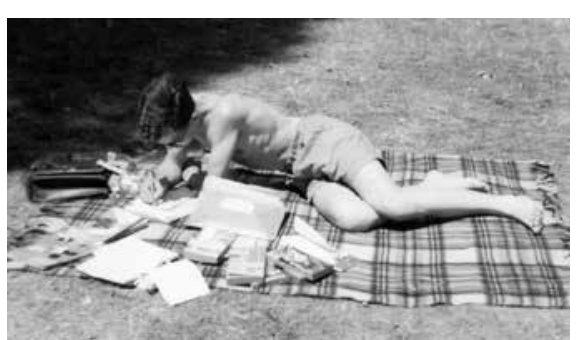

dedication and focus is destined to go new ways, to develop new thoughts, always looking for the undiscovered, always thinking out of the box.

The flipside of this might be that before really finishing something, such people are often already heading off to new horizons and discoveries. That is, I think one of the main reasons why the museological handbooks that Peter was so destined to write, were not written. Peter van Mensch is the museological thinker who expresses his thoughts in articles, (guest) lectures and workshops around the world, not in voluminous books. Numerous, relevant articles and lectures have triggered the field and rewired numerous museological brains. Peter van Mensch can be best described as the museological omnivore with more than 550 publications on his name and still counting. At the end of this small article I have put a little list of fifteen publications of Peter that he likes best, some of them are real unknown gems.

\section{The artist's artist: The} museologist's museologist

In the art world, there is a phenomenon known as the artist's artist. According to Nessia
Pope the term artist's artist can "be applied to those figures whose art possesses some strange brilliance or idiosyncratic foresightedness that their fellow creatives cannot resist."

Peter van Mensch is something of an museologist's museologist. He is maybe not known by a larger public, but that lies also in the nature of our discipline. If you would put all the important museologists worldwide in one airplane and that airplane would crash, then there would be hardly a museologist around. Not for nothing our discipline is being described by Friedrich Waidacher as an "Orchideenwissenschaft". ${ }^{2}$

You need to be in a sort of inner museological circle to know him. ${ }^{3}$ But I don' $t$ think there are many other never officially published $\mathrm{PhD}$ 's that have been translated in so many foreign languages. Some of them made accessible online, all of them made by devoted fellow museologists with a small budget. The respect and admiration for Peter his visions are very visible in these translation projects and I know it fills him with gratitude.

\footnotetext{
1 POPE, Nessia. What is an artist's artist? [online]. [cit. 2017-03-30]. Available from www: <http:// www.artspace.com/magazine/art_101>.

2 WAIDACHER, Friedrich. Von Orchideen und Disteln: Museologie im Spannungsfeld zwischen Ahnungslosigkeit und Verweigerung. Museologie Online [online]. 2003, vol. 5, pp. 1-24 [cit. 2017-03-30]. Available from www: <http://www. historisches-centrum.de/m-online/03/waidacher. pdf $>$.

3 In the Dictionnaire encyclopédique de museology, Peter van Mensch is mentioned as one of the 18 most influential museologists.
} 
Nesia Pope writes about "idiosyncratic foresightedness" as one of the mayor trait of an artist's artist. As I wrote earlier, Peter has always been interested in the new. He has been forecasting and reflecting trends in museology long before our two little books were published. ${ }^{4}$ Not for nothing it was he who incorporated futurology in the Reinwardt Academy curriculum. As well as the scanning for trends as part of a set of indispensable professional competences that every Reinwardt Academy alumni needs to process. Good examples for his foresightedness are his thoughts about the synergies between museums and management, long before the tern cultural entrepreneurship became en vogue. ${ }^{5}$

\section{In between different worlds}

Peter van Mensch wrote his $\mathrm{PhD}$ thesis, where he i.e. reflected upon the early history of ICOFOM and its mayor stakeholders, in Zagreb. ${ }^{6}$ His 'Doktorvater' was Ivo Maroević, who became a dear friend and the former Yugoslavia became a second intellectual and emotional 'Heimat'. Not for nothing Peter and also myself have close professional and emotional ties with countries like Slovenia, Croatia and Serbia.

In the Netherlands, at the end of the 1980s it was unfortunately not possible to obtain a $\mathrm{PhD}$ in museology. Peter had tried to get accepted as an external PhD candidate at the Faculty of Humanities at the University of

\footnotetext{
4 See for our second edition: MENSCH, Peter van and Léontine MEIJER-VAN MENSCH. New Trends in Museology II. Celje: Muzej novejše zgodovine, 2015. ISBN 978-961-6339-39-1.

5 MENSCH, Peter van. Museology and management: enemies or friends? Current tendencies in theoretical museology and museum management in Europe. In MIZUSHIMA, Eiji (ed.). Museum management in the 21st century. Tokyo: Museum Management Academy, 2004, pp. 3-19.

6 MENSCH, Peter van. Towards a methodology of museology. Zagreb: University of Zagreb, 1992.
} $\mathrm{PhD}$ thesis.
Amsterdam. Having a background in archaeozoology and not in humanities and moreover working at an applied university like the Reinwardt Academy made him to exotic. By not getting accepted by the academic establishment in the Netherlands at that time he decided to use his ICOM network and seek his academic fulfilment outside the national borders. He could have chosen to enrol into the museum studies program at Leicester and obtain a PhD in England. But his ICOFOM network and his interest in the Central European museological discourse - which was at that time also the dominating discourse within ICOFOM - made his choice for Zagreb a more logical one. Not only Zagreb, also Brno was a museological center in Central Europe and for many years Peter was a lecturer who played a decisive role in the International Summer School of Museology in Brno. Many of the students of the International Summer School became mayor players in museology, or in the museum world at large. These students, as well as of course the students of the International Master of Museology at the Reinwardt Academy were influenced by his thinking and they became multiplicators of his approaches in their countries of origin. A few years ago I visited Brno to study the archives of the International School of Museology and it is fascinating that most of the students back then are now either influential museological thinkers or successful people in the museum field, a lot of the directors. Good examples are the Belgium François Mairesse, now professor for museology at the Sorbonne, or Tanja Rozenbergar, a young museum professional from Slovenia, attending the Brno International School of Museology at the beginning of the nineties. Tanja Rozenbergar has now a PhD is museology and is the director of the Slovene Ethnographic Museum in Ljubljana.

\section{The Peter van Mensch approach}

The before mentioned constant scanning of trends in our field and beyond can definitely be considered a Peter van Mensch approach. Another approach is his usage of models. To be honest, when I first got to know the works of Peter, the models slightly intimidated me. Being a historian myself, academically shaped in Germany, my path towards museology went primarily via remembrance culture and material culture studies. Becoming the successor of Peter van Mensch in 2006 as a lecturer in Museum Theory and Professional Ethics at the Reinwardt Academy in Amsterdam I wanted not only to get to know the Peter van Mensch theoretical system approach, I also wanted to achieve a dialogue with these models, adopt them, make them my own.

After we became the 'museological couple' we have been developing museological models together and now I can wholeheartedly say that I can' $t$ image that there ever was a time that I did not think in models. I personally think it was this specific archaeozoological background that made him think in models in the first place. To be honest, some of them are real aesthetic beauties. My favourite model is the 'input-output model'

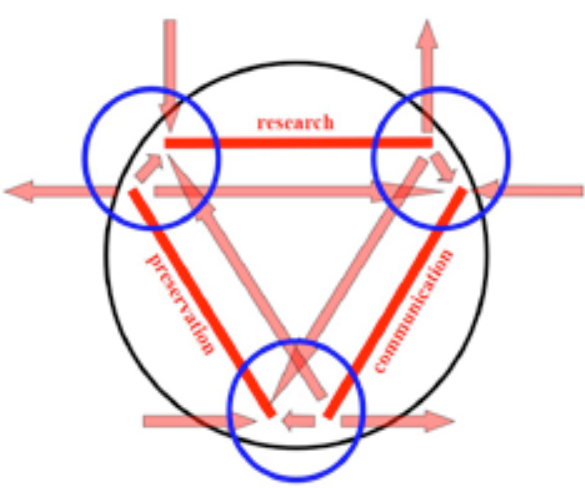

Model 1: A museum conceptualised as complex system of input-output systems 
(2004). This model visualises a system approach to the museum phenomenon. The museum is seen as a system of connected subsystems. Three subsystems are distinguished: preservation, research and communication. Each subsystem can be divided into smaller subsystems and all of them are interconnected with the museum as a whole, because the output of one subsystem serves as the input of another, or in theory all others. On paper it sounds complicated, put in a model it looks almost 'arty'.

\section{Turning seventy}

\section{On June 7th 2017 Peter van}

Mensch turns seventy. A beautiful reason to honor, to celebrate and to express wishes. First of all I hope that Peter will be among us for at least another thirty years. Moreover I hope he will enjoy his days, reading the newspapers in a Berliner café in the morning, visiting museums in the afternoon and drinking a good glas of red wine in the evening. I hope, no I am confidedent that he will stay a source of inspiration for us all and the field at large. Although I hope he will he will spend more time with his children and grandchildren and that he will be working much more in our garden or just do nothing, I hope that he finally finds the time and the concentration to start writing all this voluminous works. There is still so much in his heart, soul and intellect that needs to be said and written down. If there is somebody who rocks and who can turn our orchid science into something else, it is Peter van Mensch. I am honored to be his wife, mazzeltov my dear!

\section{His own fifteen best:}

Peter J. A. van Mensch, Piet J. M. Pouw

\& Frans F. J. Schouten. Methodology of museology and professional training. A contribution to the discussion. In Vinoš Sofka (ed.) Methodology of museology and professional training. ICOFOM Study Series 1. Stockholm, 1983, pp. 81-94.

Peter van Mensch. The extension of the museum concept. Museumvisie (special ICOM'89 issue), vol. 7, pp. 20-24.

Peter van Mensch (ed.). Professionalising the Muses. The museum profession in motion. Discours II. Amsterdam: AHA Books, 1989.

Peter van Mensch. Museums in the Netherlands: an "embarrassment of riches". Museum, 1989, vol. 162, pp. 120123.

Peter van Mensch. Voor nu en voor later. Amsterdam: Nederlandse Museumvereniging, 1993.

Peter van Mensch. Convergence and divergence. Museums of science and technology in historical perspective. In Cyril Simard (ed.). Des métiers ... de la tradition à la creation. Anthologie en faveur d'un patrimoine qui gagne sa vie. Sainte-Foy: Gid, 2003, pp. 342-352.

Peter van Mensch. De uitvinding van het verleden. Jonkheer Henri van Sypesteyn op zoek naar zijn stamslot. In Rob van der Laarse \& Yme Kuiper (red.). Beelden van de Buitenplaats. Elitevorming en notabelencultuur in Nederland in de negentiende eeuw. Adelsgeschiedenis 3. Hilversum: Verloren, 2005, pp. 195-210.

Peter van Mensch. Annotating the environment. Heritage and new technologies. Nordisk Museologi, 2005, no. 2, pp. 14-27.

Peter van Mensch. Pantheon, museum of historisch huis? Drie inrichtingsmodellen voor het Muiderslot. In Muiderslot. Authenticiteit en verbeelding. Jaarboek Cuypersgenootschap 2008, pp. 39-54.

Peter van Mensch. Développer la collection ou gagner de l'argent? Les dilemmes de l'aliénation. In François Mairesse (red.). L'alienation des collections de musée en question. Mariemont, 2009, pp. 69-73.

Léontine Meijer-van Mensch and Peter van Mensch. From disciplinary control to cocreation. Collecting and the development of museums as praxis in the nineteenth and twentieth century. In Encouraging collections mobility - a way forward for museums in Europe. Helsinki: Finnish National Gallery, 2010, pp. 33-53.

Peter van Mensch \& Léontine Meijer-van Mensch. New Trends in Museology. Celje: Muzej novejše zgodovine, 2011. Second edition 2015.

Peter van Mensch. Catching the space between the objects. In Werner van Hoof (ed.). Catching the Spirit. Theatrical Assets of Historic Houses and their Approaches in Reinventing the Past. Proceedings of the ICOM/DEMHIST international conference, Antwerp, 17-20 October 2011. Antwerp: Museum Plantin Moretus, 2012, pp. 1219.

Peter van Mensch. "Against all norms and values": dilemma of collecting controversial objects. In Jacques Battesti (ed.). Que reste- $t$-il du présent? Collecter le contemporain dans les musées du société. Bordeaux: Le Festin, 2012, pp. 138-145.

Peter van Mensch. Museality at breakfast. The concept of museality in contemporary museological discourse. Museologica Brunensia, 2015, vol. 4, no. 2, pp. 14-19.

LÉONTINE MEIJER-VAN MENSCH Jewish Museum Berlin, Germany 